\title{
Egypt: NGOs need to join forces to end FGC
}

Frontiers in Reproductive Health

Follow this and additional works at: https://knowledgecommons.popcouncil.org/departments_sbsr-rh

Part of the Public Health Education and Promotion Commons, and the Women's Health Commons How does access to this work benefit you? Let us know!

\section{Recommended Citation}

"Egypt: NGOs need to join forces to end FGC," FRONTIERS OR Summary. Washington, DC: Population Council, 2000. 


\section{Egypt FGC}

OR Summary 14

\title{
NGOs Need to Join Forces to End FGC
}

\begin{abstract}
Fifteen Egyptian non-governmental organizations are actively involved in programs to eradicate the practice of female genital cutting. To make these programs more effective, NGOs should form coalitions, engage in advocacy, train activists in communication skills, and evaluate the impact of their programs.
\end{abstract}

\section{Background}

Until recently, the practice of female genital cutting (FGC) has been nearly universal in Egypt. However, a 1998 national survey found the first signs of a decline in the practice among adolescents since 1994 (ElGibaly et al., 1999).

Non-governmental organizations (NGOs) working in community development, health and women's rights have played a leading role in advocating eradication of FGC in Egypt. To document and assess the impact of anti-FGC programs, the Population Council conducted an assessment from August 1999 to February 2000. Researchers telephoned numerous Egyptian NGOs to identify those most actively involved in antiFGC programs. Then they conducted in-depth interviews with officials of 15 NGOs.

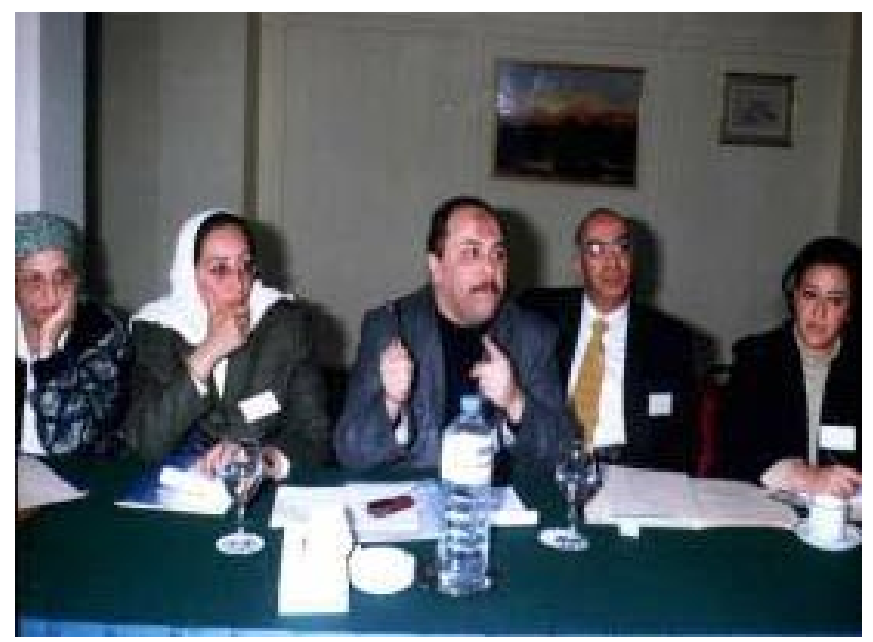

as well as staff of the Ministry of Health and Population, UNICEF and the United Nations Population Fund (UNFPA).

\section{Findings}

- Most NGOs had no evaluation mechanism in place to assess the impact of their interventions. Some NGOs collect information on process indicators, such as the number of meetings, attendees, and requests for information. Few NGOs measure the impact of their interventions on participants' knowledge, attitudes, or practices.

- Each of the four basic intervention models identified in the assessment was useful in addressing some aspect of the behavior change continuum, from creating awareness to increasing knowledge, to talking with others about FGC, culminating in the decision to take a firm stand against FGC. The four intervention models are:

$\downarrow$ Awareness-raising. Many NGOs have organized large lectures and seminars for community members, with medical and religious leaders discussing the harmful effects of FGC. Such meetings reach large numbers of people at a relatively low cost.

\& Community members as change agents. Some NGOs have trained influential community members or individuals who are opposed to FGC (positive deviants) to talk to others in their 
community. NGO leaders reported that this approach did lead to knowledge gains and attitude change regarding FGC.

\section{$\downarrow$ Community development. Several NGOs} have integrated anti-FGC messages into literacy classes and a program for handicapped youth. A few NGOs have added anti-FGC components to their comprehensive development programs. This approach is promising, since it targets the entire community and reaches individuals through multiple channels such as seminars, home visits and literacy classes. However, it is expensive and labor-intensive.

$\downarrow$ Advocacy. A few NGOs have done advocacy work such as: organizing meetings of government officials; providing information to politicians, researchers and journalists; building coalitions with other NGOs; training local leaders in advocacy skills; and producing radio and television programs on FGC.

- Although most NGO officials recognized the importance of networks and coalitions for combating FGC, only two NGOs belong to such groups.

\section{Policy Implications}

At a two-day seminar held in January 2000 in Cairo, 40 representatives of NGOs, government agencies, research institutes, donor agencies, and Cooperating Agencies discussed the assessment findings and recommended that:

- NGOs should form coalitions to reinforce and complement each other's work. They should involve government agencies, media outlets, research institutions, and communities in broad-scale interventions.

- More advocacy activities, particularly those that combine media and policy activities, are needed to create a strong social and political environment against FGC in Egypt.

- Anti-FGC messages should discuss social, religious and legal perspectives rather than focusing on the health hazards of FGC.

- NGOs should develop partnerships with research institutions to obtain technical assistance in evaluation. They should develop indicators to measure the different stages of attitude and behavior change.

- Outreach workers and community advocates need training in communication techniques and problemsolving skills, assistance in defining their activities, and better supervision.

Abdel-Tawab, Nahla, and Sahar Hegazi.2000. "Critical Analysis of Interventions against FGC in Egypt.” Cairo: Population Council. For more information or to obtain a copy of the English Final Report or the Arabic Condensed Summary of this study, contact: Population Council, 6 A Mohamed Bahie Eddine Barakat St., 10 floor, Giza, Egypt. Tel.: 202-571-9252; Fax: 202-570-1804; E-mail: frontiers@pccairo.org .

This project was conducted with support from the U.S. AGENCY FOR INTERNATIONAL DEVELOPMENT under Cooperative Agreement Number HRN-A-00-98-00012-00. 